\title{
Clinical Microbiology: Reemphasizing the Role of Anaerobic Bacteria in Hu- man Infections
}

\section{K V Ramana}

Department of Microbiology, Prathima Institute of Medical Sciences, nagunur, Karimnagar, Andhra pradesh, India

\section{Introduction}

Life in the absence of air is known as anaerobiosis. Oxygen free environment is suitable for growth of bacteria which are termed as anaerobic bacteria was first observed by Antony Van Leeuwenhoek. Clostridium butyricum was the first anaerobic bacteria discovered by Louis $\mathrm{Pa}$ steur in 1862 and he has coined the term anaerobies for those bacteria which grow in the absence of air. First report of infection in human by anaerobic bacteria was attributed to Bacteroides fragilis by Veillon and Zuber way back in 1893 [1]. Anaerobic bacteria that cannot grow in the presence of more than $0.5 \%$ oxygen are termed as strict anaerobes and those that can sustain $2-8 \%$ of oxygen are called as facultative anaerobes [2]. Anaerobic bacteria live in the oxygen free pockets of human body including the interiors of plaques on the surfaces of teeth, gums and in the gastrointestinal tract. It is really astonishing to know that anaerobic bacteria outnumber the aerobic bacteria as human flora being present even on skin. Most of the anaerobic infections in human are endogenous in origin ever since they were recognized as being responsible for various infections in human as well as animals [3]. More than hundred years since anaerobes and the infections caused by anaerobic bacteria were recognized, lest very less progress has been achieved that can be attributed to complacence, negligence and ignorance among the clinicians and clinical microbiologists.

\section{Identification of Anaerobic Bacteria}

From the time since discovery of anaerobic bacterial infections, very less progress has been achieved which included anaerobic apparatus like gas paks, Coy anaerobic chambers, pre-reduced anaerobically sterilized media (PRAS) and sodium azide selective medium for selective culture of anaerobes were used in clinical laboratories [4-6]. Identification of Anaerobic bacterial isolates from various clinical isolates was studied based morphological characters like pigment production and their susceptibilities to six antibiotics including penicillin, erythromycin, rifampicin, kanamycin, vancomycin and colostin $[7,8]$. Due to more turnaround time for their culture, identification and sensitivity and the cost, routine anaerobic bacteriology of various clinical isolates was not considered in many clinical laboratories. The fact that anaerobic infections are normally polymicrobial makes it even more difficult for their culture as clinical samples are processed routinely for aerobic bacteria. Anaerobic bacteria were considered to act synergistically with coexisting aerobic pathogens to produce specific lesions which otherwise would have developed typical infections independently [9-11]. Bacteremia due to anaerobic microorganisms though has been reported frequently, blood for culture of anaerobes is still is not regularly performed in many clinical laboratories [12]. Developing countries face cost constraints in acquiring and processing clinical samples for both aerobic and anaerobic bacteria. Clinically relevant anaerobic bacteria include Bacteroides fragilis group (Bacteroides fragilis, $B$ thetaiotamicron, $B$ ureolyticus, $B$ stercoris, $B$ caccae, $B$ merdae, $B$ distasonis, $B$ uniformis, $B$ ovatus and $B$ vulgates), Pigmented anaerobic gram negative bacteria (Prevotella melaninogenics, $P$ denticola and $P$ nigrescens) and non-pigmented prevotella ( $P$ oralis) [3]. Other anerobic bacteria that are isolated frequently in clinical samples include Clostridium perfrin- gens, Clostridium difficle, Peptostreptococcus micros, Peptostreptococcus magnus, Porphyromonas asacharolyticus, Fusobacterium nucleatum, $F$ necrophorum, F varium, F russii and Bilophila wadsworthia. Bifidobacterium, Eubacterium, Lactobacillus, Propionibacterium and Actinomyces spp. form a part of indigenious flora of humans $[5,10,13]$.

\section{Pathology of Anaerobic Bacterial Infections}

Anaerobic infections most often present as abscesses. Very little has been understood about the pathogenesis of anaerobic bacterial infections. Though many anaerobic bacteria do not possess biologically active endotoxins, capsular polysaccharide, synergistic association with other bacteria (poly microbial infections), action of anaerobic bacteria on living and dead tissue to form gas, impairment of defence mechanism due to anoxia, various conditions that reduce oxidation- reduction potential may produce characteristic anaerobic infections. From skin and soft tissue infections, periodontal infections, bite wound, traumatic wounds, anaerobes can involve head and neck, lungs, GIT and genitorurinary tract $[3,14-16]$. Anaerobic infections are normally localized near mucus membranes and involve degenerating tissue either due to bacterial action or with enzymatic action. Predisposing factors for anaerobic bacterial infections include tissue anoxia either due to trauma or because of surgery, malignancy and vascular abnormalities. Endocrine disorders including Diabetes mellitus, spleenectomy, immunosuppression either due to cytotoxic drugs or because of HIV and other infections $[3,10]$.

\section{Therapeutic Management of Anaerobic Infections}

Antibiotic prophylaxis is often practiced in clinical practice to combat anaerobic bacterial infections. Clindamycin for respiratory infections, metronidazole and fluoroquinolones for GIT and other surgeries are some of the antibiotics employed to eliminate anaerobic infections [17]. Resistance to antibiotics though is not common, reports of resistance of anaerobic bacteria to many commonly used drugs has been on the rise $[18,19]$. Carbapenem and 5- nitroimidazoles are the two groups of antibiotics which still show a lot of promise [10]. Aminoglycisides are ineffective in anaerobic infections due to absence of oxygen and nitrogen electron transport system which is required for uptake [10]. Molecular mechanisms of resistance include inter or intra generic transfer of resistance by conjugation and transformation under anaerobic

*Corresponding author: $\mathrm{K} V$ Ramana $\mathrm{PhD}$, Assistant Professor of Microbiology, Department of Microbiology, Prathima Institute of Medical Sciences, nagunur, Karimnagar, Andhra pradesh, India, E-mail: ramana_20021@rediffmail.com

Received June 14, 2012; Accepted June 19, 2012; Published June 25, 2012

Citation: Ramana KV (2012) Clinical Microbiology: Reemphasizing the Role of Anaerobic Bacteria in Human Infections. J Med Microb Diagn 1:e109. doi:10.4172/2161-0703.1000e109

Copyright: (c) 2012 Ramana KV. This is an open-access article distributed under the terms of the Creative Commons Attribution License, which permits unrestricted use, distribution, and reproduction in any medium, provided the original author and source are credited. 
environment. Plasmids also were found responsible for drug resistance in anaerobic bacteria [20-22].

\section{Current Perspective and Future Implications}

Interest on anaerobic microbiology has taken a new upsurge due to increasing reports of infections with anaerobic bacteria including Bacteroides group, Clostridium difficle and animal infection outbreaks caused by Clostridium botulinum [16]. Bacterial therapeutics, use of bacteria for drug delivery, a new area of research concentrating on treatment of cancers with use of anaerobic bacteria to carry the antibiotics or anti cancer reagents to the hypoxic, low $\mathrm{pH}$ and microenvironments inside the cancerous tissue has been instrumental in generating some interest in anaerobic bacteria $[23,24]$. Thermophilic anaerobic bacteria are a cause of concern in food industry that brings about spoilage of non or semi-acid canned foods and can be responsible for outbreaks [6]. The main drawback for reduced isolation of anaerobic bacteria from various clinical samples was improperly collected and transported specimen. Developing countries are ill supported financially to establish a separate anaerobic section in diagnostic laboratory. Though many aerobic blood cultures are negative, no efforts are made to process blood for anaerobic culture. Previous reports have suggested significance of anaerobic blood cultures in ICU's and a 3\% positivity of obligate anaerobes among the study group $[25,26]$. No adequate data is available either on the frequency of anaerobic bacterial infections, predisposing factors or on the in vitro antimicrobial susceptibility patterns of anaerobic bacteria isolated from clinical specimens. Interest on anaerobic bacterial identification and their susceptibility towards various antimicrobial agents can only be attained if clinicians suspect anaerobic bacterial infections and availability of trained paramedical staff on the necessary precautions to be taken for proper collection and transport of specimens where ever anerobic bacteria are to be suspected. Clinical microbiologists should work in synergy with clinicians, Conduct Continuing Medical Education (CME) programmes on anaerobic bacteria and their role in infections, give necessary training for paramedical staff and establish necessary laboratory facilities for identification of anaerobes in the suspected clinical specimens.

\section{References}

1. Veillon $A$ (1893) Sur un microcoque anaeÂrobie trouveÂ dans des suppurations fetides. C R Soc Biol (Paris) 45: 807-809.

2. Loesche WJ (1969) Oxygen sensitivity of various anaerobic bacteria. Appl Microbiol 18: 723-727.

3. Barlett J G (2002) An update on mixed aerobic and anaerobic infections. Adv Stud Med 2: 104-109.

4. McIntosh J, Fildes $P$, Bulloch W (1916) A new apparatus for the isolation and cultivation of anaerobic microorganisms. The Lancet 187: 768-770.

5. Forget A, Fredette $V(1962)$ Sodium azide selective medium for the primary isolation of anaerobic bacteria. J Bacteriol 83: 1217-1223.

6. McClung LS (1935) Studies on Anaerobic Bacteria: III. Historical Review and Technique of Culture of Certain Thermophilic Anaerobes. J Bacteriol 29: 173187.

7. Finegold SM (2000) Anaerobic Infections: General Concepts. In Principles and Practice of Infectious Diseases, vol. 2. Edited by Mandell GL, Bennett JE, Dolin R. Philadelphia: Churchill Livingstone; 2000: 2519-2537.

8. Robertson D, Smith AJ (2009) The microbiology of the acute dental abscess. $J$ Med Microbiol 58: 155-162.

9. Brook I (2008) Ocular infections due to anaerobic bacteria in children. J Pediatr Ophthalmol Strabismus 45: 78-84.

10. Jenkins SG (2001) Infections due to anaerobic bacteria and the role of antimicrobial susceptibility testing of anaerobes. Reviews in Medical Microbiology 12: $1-12$.
11. New aspects of anaerobic bacterial infections. Journal of Clinical Microbiology and Infection, Volume 3 Supplement 2 31-32.

12. Brook I (2010) The role of anaerobic bacteria in bacteremia. Anaerobe 16: 183189.

13. Finegold S, Summanen P, Hunt Gerardo S, Baron E (1992) Clinical importance of Bilophila wadsworthia. Eur J Clin Microbiol Infect Dis 11: 1058-1063.

14. Brook I (2011) Anaerobic infections in children. Adv Exp Med Biol 697: 117-152.

15. Lassmann B, Gustafson DR, Wood CM, Rosenblatt JE (2007) Reemergence of Anaerobic Bacteremia. Clin Infect Dis 44: 895-900.

16. Bharadwaj R (2012) Anaerobic microbiology: time to rejuvenate. Indian J Med Microbiol 30: 3-5.

17. Bartlett JG, Sutter VL, Finegold SM (1972) Treatment of anaerobic infections with lincomycin and clindamycin. N Engl J Med 287: 1006-1010.

18. Antibiotic sensitivity testing of anaerobic bacteria - Workshop arranged by ESGARAB Clinical Microbiology and Infection, Volume 11, Supplement 2, 2005 $1-98$.

19. Staneck JL, Washington JA 2nd (1974) Antimicrobial susceptibilities of anaerobic bacteria: recent clinical isolates. Antimicrob Agents Chemother 6: 311-315.

20. Stein GE, Goldstein EJ (2006) Fluoroquinolones and anaerobes. Clin Infect Dis 42: 1598-1607.

21. Levison ME, Bran JL, Ries K (1974) Treatment of anaerobic bacterial infections with clindamycin-2-Phosphate. Antimicrob Agents Chemother 5: 276-280.

22. Nagy E (2010) Anaerobic infections: update on treatment considerations Drugs 70: 841-858.

23. Linnebacher M, Maletzki C, Klier U, Klar E (2012) Bacterial immunotherapy of gastrointestinal tumors Langenbecks. Arch Surg 397: 557-568.

24. Taniguchi S, Fujimori M, Sasaki T, Tsutsui H, Shimatani Y, et al. (2010) Targeting solid tumors with non-pathogenic obligate anaerobic bacteria. Cancer Sci 101: 1925-1932.

25. Byrd RP Jr, Roy TM (2003) Anaerobic blood cultures: useful in the ICU? Chest 123: 2158-2159.

26. Lombardi DP, Engleberg NC (1992) Anaerobic bacteremia: incidence, patient characteristics, and clinical significance. Am J Med 92: 53-60. 